\title{
Rodamin 123 Etiketli Bor Nitrür Nanoparçacıklarının Karakterizasyonu ve in vitro Biyogörüntüleme Potansiyelinin Araştırılması
}

\section{Characterization of Rhodamine 123-Labeled Boron Nitride Nanoparticles and Investigation of in vitro Bioimaging Potential}

Erdal Eroğlu *

Manisa Celal Bayar Üniversitesi, Mühendislik Fakültesi, Biyomühendislik Bölümü, Manisa, TÜRKiYE Sorumlu Yazar / Corresponding Author*: erdal.eroglu@cbu.edu.tr

\author{
Geliş Tarihi / Received: 25.08.2020 \\ Araștırma Makalesi/Research Article \\ Kabul Tarihi / Accepted: 07.12.2020 \\ DOI:10.21205/deufmd.2021236821 \\ Atıfsekli/How to cite EROĞLU, E. (2021). Rodamin 123 Etiketli Bor Nitrür Nanoparçacıklarının Karakterizasyonu ve in vitro Biyogörüntüleme
} Potansiyelinin Araștırılması. DEUFMD 23(68), 595-605.

\section{Öz}

Bu çalışmanın amacı bor nitrür (BN) nanoparçacıklarının floresan bir boya olan rodamin 123 (Rd) ile etiketlenmesi ve biyogörüntüleme amaçlı kullanımının in vitro ortamda araştırılmasıdır. Öncelikli olarak, rodamin 123 etiketi bor nitrür nanoparçacıklarına glutaraldehid çapraz bağlayıcısı aracılığıyla bağlanarak BN-Rd nanoparçacıkları üretilmiş ve SEM, UV-görünür bölge spektroskopisi, MTT hücre proliferasyon testi, ışı mikroskobu ve floresan mikroskobu analizleri ile karakterize edilmiştir. Sitotoksik olmayan konsantrasyonlardaki BN-Rd nanoparçacıkları insan prostat kanseri hücreleri (PC-3) ile insan embriyonik böbrek hücreleri (HEK-293) üzerine uygulanmıș ve hücreler floresan mikroskobu altında incelenerek BN-Rd'nin biyogörüntüleme potansiyeli in vitro ortamda araștırılmıştır. Sonuç olarak, SEM analizlerinde $\sim 40 \mathrm{~nm}$ boyuta sahip olduğu belirlenen BN ve BN-Rd $30 \mu \mathrm{g} / \mathrm{ml}$ ve üzerindeki konsantrasyonlarda sitotoksik etki göstermiştir. Işılk mikroskobu altında incelenen nanoparçacık uygulanmış hücre morfolojileri MTT sonuçlarını destekler nitelikte bulunmuştur. Her iki hücre hattı üzerine de uygulanan BN-Rd'nin $10 \mu \mathrm{g} / \mathrm{ml}$ konsantrasyonda hücreler ile etkileşime geçtiği ve hücrelerin in vitro ortamda floresan mikroskobu altında ışıma yaptığı gözlenmiştir. Bu çalışmadan elde edilen bulgular ışı̆̆ında rodamin 123 floresan boyası ile etiketli bor nitrür nanoparçacıklarının biyogörüntüleme uygulamalarında kullanım potansiyeli ortaya konmuştur.

Anahtar Kelimeler: Bor Nitrür Nanoparçacıkları, Rodamin 123, Biyogörüntüleme

\section{Abstract}

The aim of this study is to label boron nitride (BN) nanoparticles with a fluorescent dye, rhodamine 123 (Rd), and to investigate its use for bioimaging in vitro condition. First, BN-Rd nanoparticles were produced by binding rhodamine 123 tag to boron nitride nanoparticles via glutaraldehyde crosslinker and characterized by SEM, UV-visible spectroscopy, MTT cell proliferation test, light microscope and fluorescence microscope analyses. BN-Rd nanoparticles at non-cytotoxic concentrations were applied on human prostate cancer cells (PC-3) and human embriyonic kidney cells (HEK-293) and the 
bioimaging potential of BN-Rd was investigated in vitro by examining the cells under fluorescence microscopy. As a result, BN and BN-Rd, which were determined to have a size of $\sim 40 \mathrm{~nm}$ in SEM analysis, showed a cytotoxic effect at concentrations of $30 \mu \mathrm{g} / \mathrm{ml}$ and above. The nanoparticle-treated cell morphologies examined under a light microscope was found to support MTT results. It was observed that BN-Rd, at a concentration of $10 \mu \mathrm{g} / \mathrm{ml}$ applied on both cell lines interacted with the cells and the cells fluoresced under a fluorescence microscope in vitro. In the light of the findings obtained from this study, the potential use of boron nitride nanoparticles labeled with rhodamine 123 fluorescent dye in bioimaging applications has been revealed.

Keywords: Boron Nitride Nanoparticles, Rhodamine 123, Bioimaging

\section{Giriş}

Biyolojik görüntüleme olarak da bilinen biyogörüntüleme, hastalıkların teșhisinde ve tedavisinde sıklıkla kullanılan biyolojik bileșenlerin takip edilmesine dayanan noninvazif bir tekniktir [1,2]. Hareket solunum gibi yaşamsal faaliyetleri etkilemeden hücre içi yapıların veya canlılardaki dokuların üç boyutlu olarak gözlemlenmesini sağlamaktadır [3]. Son yıllarda, oldukça verimli yeni floresan probların geliștirilmesi ve buna paralel olarak mikroskobi tekniklerinin daha yüksek seviyeye ulaşması, biyogörüntüleme alanında görüntü kalitelisini arttırıldığı üst düzey teknolojilerin üretilmesini sağlamıştır [1]. Örnek olarak, floresan boyalarla etiketli nanotaşıyıcıların canlı sistemlerde ve hücre modellerinde taşınımının takip edilmesine dayanan floresan biyogörüntüleme, yeni bir akım olarak karşımıza çıkmaktadır. Özellikle farklı problarlarla etiketlenmiş ve ligandlarla hedefe yönlendirilmiș nanotașıyıcıların kanserli dokunun görüntülenmesinde kullanımı rutin olarak araştırılan konuların başında gelmektedir [4].

Floresin, rodamin, fikobiliprotein, yeșil floresan proteini ve porfirin gibi farkl floroforların biyogörütüleme amaçlı kullanımı yaygın olarak kabul görmektedir [5]. Florofor tiplerinden biri olan rodamin $123505 \mathrm{~nm}$ 'de absorpsiyon ve 525 nm'de de floresan ışıma yapması sebebiyle kimya, biyoloji ve tıp gibi farklı alanlarda kullanılmaktadır. Nispeten toksisitesinin düşük olması, ucuz olması, ticari olarak kolay tedarik edilebilmesi, yüksek kuantum verimi, noninvazif olarak tespit edilebilir olması, hücre zarını kolayca geçebilmesi, hücre içi metabolik yolakları etkilememesi ve mitokondride birikerek hücreyi boyaması gibi sebepler, rodamin boyasını biyogörüntülüme ve ilaç aktarımı gibi çalıșmalarda tercih edilir hale getirmiștir [6,7].
Nanoparçacıklar birçok fiziksel ve kimyasal üstün özelliklere sahip olması sebebiyle ilaç/antioksidant madde aktarımından biyogörüntülemeye kadar geniş alanda kullanım potansiyeline sahiptirler $[7,8,9]$. Aktarımı yapılmak istenen etken madde porlu yapıdaki nanomalzemelere daha verimli şekilde yüklenebilirken yüzeylerinde bulundurdukları yüksek orandaki serbest atomlar, fonksiyonel grupların kovalent olarak bağlanmasına olanak sağlamaktadır. Nanoparçacıkların boyutları ayarlanabilmekte ve yüzey modifikasyonları ile nanoparçacıklara istenilen özellikler kazandırılabilmektedir $[7,10]$. Pasif hedefleme, tümörlü bölgedeki hücreler arasındaki mesafenin normal dokudaki hücrelere oranla daha açık olması ve buna bağlı olarak tümörlü dokunun 40-200 nm aralığındaki nano-yapılara daha geçirgen olması olarak tanımlanmaktadır. Tümörlü dokuda pasif hedefleme ile 10-100 kat daha fazla nanoparçacık birikimi olduğu gözlenmiștir [11,12].

Doğal olarak bulunmayan bor nitrür, bor ve azotun bir araya getirilmesiyle sentetik olarak üretilmektedir. Beyaz karbon veya beyaz grafit olarak da isimlendirilen bor nitrürün kristal yapısı karbona benzemektedir. Üstün kimyasal, elektriksel ve isıl özelliklere sahip bir bileşik olan bor nitrür, elektrik-elektronik endüstrisinden seramik endüstrisine kadar bir çok alanda kullanılmaktadır $\quad[13,14]$. Dünya bor rezervlerinin \%73'ünü elinde bulunduran ülkemizde \%36'sı cam, \%31'i seramik, \%9'u temizlik-deterjanı, \%7'si tarım, \%4'ü tutkal ve \%14'ü diğer alanlar [15] olmak üzere kullanılan borun katma değeri daha yüksek, biyomedikal alanında da kullanılabilen ürünlere dönüştürülmesi ülke ekonomisi için oldukça önemlidir. Bor nitrür nanoparçacıkları üzerine yapılan araștırma sayısı çalıșılan diğer 
nanomalzemelere oranla oldukça geride kalmıştır. Buna rağmen son yıllarda bor ve türevlerinin kullanıldığı ilaç aktarımı ve biyogörüntüleme gibi farklı alanlardaki araştırmalar ilgi çekmeye başlamıştır [16-18].

Literatürdeki mevcut çalışmalarla, kalsiyum fosfat [19], silika [20], karbon [21], gümüş [22], jelatin-metakrilol [23] gibi farklı nanomalzemelerin biyogörüntüleme amaçlı kullanım potansiyeli ortaya konmuştur. Ayrıca, bor nitrür nanopulları [24], bor nitrür nano yaprakları [25] ve bor nitrür nanotüpleri [7] gibi farklı morfolojilere sahip bor nitrür türevlerinin biyogörüntüleme uygulamalarında kullanılanileceği belirtilmektedir. Bugüne kadar yapılan çalıșmalarda, rhodamin 123 floresan boyasıla etiketlenmiş bor nitrür nanokürelerinin biyogörüntüleme potansiyeli araştırılmayan konular arasındadır. Yaptı̆̆ımız bu çalışmada, rodamin 123 floresan boyası ile etiketlenen bor nitrür nanoparçacıklarının (BNRd) biyogörüntüleme amaçlı kullanımı in vitro ortamda ilk defa araştırılmıştır. Böylece bor ürünlerinin katma değeri daha yüksek alanlarda kullanım potansiyeli ortaya konmuștur (Șekil 1).

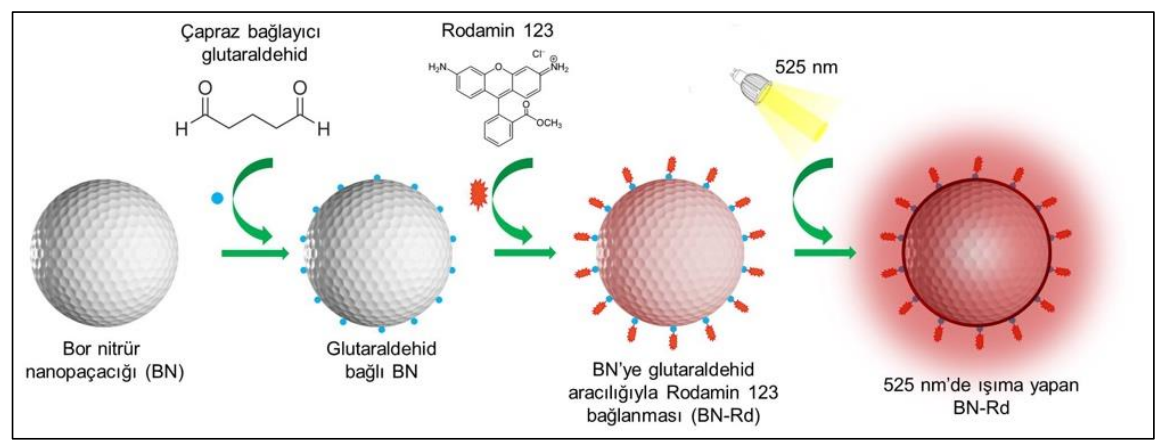

Şekil 1. Bor nitrür nanoparçacıklarına rodamin 123 etiketinin bağlanması ve biyogörüntüleme amaçlı kullanımı.

\section{Materyal ve Metot}

\subsection{Materyal}

İnsan embriyonik böbrek hücreleri (HEK-293) Dr. Öğr. Üyesi Ersin AKINCI'dan ve insan prostat kanseri hücreleri (PC-3) Doç. Dr. Harika ATMACA'dan temin edilmiştir. Dulbecco's Modified Eagle's (DMEM) besiyeri, fetal sığır serumu (FBS) ve tripan mavisi Gibco firmasindan, esansiyel olmayan aminoasit Capricorn firmasından, antibiyotik/antimikotik Biological Industries firmasından, glutaraldehid ve MTT boyası (thiazolyl blue tetrazolium bromide) Sigma firmasından, dimetil sülfoksit (DMSO) Merck firmasından, tripsin Biowest firmasından ve bor nitrür nanoparçacıkları (40$50 \mathrm{~nm}$ ) Nanokar firmasından satın alınmıștır.

\subsection{BN nanoparçacığına rodamin 123} bağlanması

Ticari bir firmadan satın alınan BN nanoparçacıkları $(10 \mathrm{mg} / \mathrm{ml})$ deiyonize su $(\mathrm{d}-\mathrm{su})$ içerisinde süspanse edilmiştir. Süspansiyona glutaraldehid $(\% 0,1)$ ve rodamin $123 \quad 100$ $\mu \mathrm{g} / \mathrm{ml}$ ) eklendikten sonra solüsyon karıștırıcı üzerinde $40^{\circ} \mathrm{C}$ sıcaklıkta $200 \mathrm{rpm}$ dönüş hızında
72 saat karıştırılmıştır. Reaksiyon sonunda, karıșım $15.000 \quad$ rpm'de santrifüjlenerek nanoparçacıklar dibe çöktürülmüş ve serbest haldeki bağlanmayan rodamin kalıntıları süpernatanla birlikte ortamdan uzaklaştırılmıştır. Daha sonra, nanoparçacık pelleti iki defa daha d-su ile yıkanmıștır. Yıkama işlemi sırasında nanoparçacıkları sıvı ortamdan ayırmak için, santrifüj işlemi tekrar edilmiștir. Son yıkamadan sonra elde edilen nanoparçacıklar $37^{\circ} \mathrm{C}$ sıcaklıktaki bir etüvde bir gece bekletilerek kurutulmuștur. Elde edilen toz haldeki nanoparçacıklar karanlık bir ortamda oda sıcaklığında kullanılıncaya kadar ependorf tüp içerisinde muhafaza edilmiștir. Nanoparçacıklar deneylerde kullanılmadan önce $\mathrm{d}$-su içerisinde süspanse edilerek $(1 \mathrm{mg} / \mathrm{ml})$ stok solüsyon hazırlanmış ve $5 \mathrm{dk}$ sonikatörde tutularak homojenizasyon sağlanmıștır.

\subsection{BN/BN-Rd nanoparçacıklarının floresan mikroskobunda görüntülenmesi}

BN-Rd'nin ıșıma yapıp yapmadığını belirlemek için yapılan bu analizde, cam bir lam üzerine yayılan bir miktar stok solüsyon hiçbir işlem 
yapılmadan direk olarak floresan mikroskobu altında görüntülenmiștir.

\subsection{UV-görünür bölge spektroskopisi}

BN ile Rd arasındaki etkileşimi gösterebilmek için ultraviyole görünür bölge (UV-GB) spektroskopisi analizi yapılmıştır (Thermo Scientific Evolution 201). d-su içerisinde seyreltilen $\mathrm{BN}$ ve BN-Rd nanoparçacıkları küvet içerisine aktarılarak 250-400 nm aralığındaki floresan spektrumda incelenmiștir.

\subsection{Taramalı elektron mikroskobu analizi}

BN ve BN-Rd nanoparçacıklarının morfolojileri ve boyutları taramalı elektron mikroskobu (SEM) (Carl Zeiss 300VP) kullanılarak incelenmiştir. Analiz için toz haldeki BN veya BN-Rd nanoparçacıkları cam bir yüzey üzerine yayılmış ve direk olarak elektron mikroskobunda incelenmiştir. SEM görüntüleri üzerinde rastgele seçilen en az 200 farklı nanoparçacığın boyutu ImageJ programı kullanılarak ölçülmüş ve ölçümlerin ortalaması alınarak nanoparçacıkların boyutları belirlenmiștir. Ayrıca, element kompozisyonuna bağlı olarak BN nanoparçacıklarının varlığını doğrulamak için enerji dağılımlı X-ıșını (EDX) spektroskopisi kullanılmıştır.

\subsection{Hücre kültürü çalışmaları}

$\mathrm{Bu}$ çalışmada özellikle insan kaynaklı hücre hatları tercih edilmiş olup, kanser modeli olarak insan prostat kanseri hücreleri (PC-3) ve normal hücre modeli olarak epitel hücresi olan insan embriyonik böbrek hücreleri (HEK-293) kullanılmıştır. Her iki hücre tipi de \%10 FBS, \%1 antibiyotik/antimikotik ve $\% 1$ esansiyel olmayan aminoasitleri içeren besiyerinde (DMEM-10) $37^{\circ} \mathrm{C}^{\prime}$ de $\% 5 \mathrm{CO}_{2}$ ortamında tutularak büyütülmüşlerdir. Her deney öncesinde, tripsinizasyon işlemi ile toplanan hücreler tripan mavisi ile boyanarak hücre canlılığı belirlenmiş ve hücre canlılığı \%90'ın altında olan kültürler deneylere dahil edilmemiștir. Hücre sayımı Neubauer sayım kabı kullanılarak yapılmıştır.

\subsection{MTT hücre proliferasyon testi}

BN ve BN-Rd nanoparçacıklarının hücreler üzerindeki sitotoksik etkisi MTT hücre proliferasyon testi kullanılarak belirlenmiștir. Tiripsinizasyon işlemi ile toplanan ve sayımı yapılan hücreler DMEM-10 besiyeri içerisinde seyreltilerek süspansiyon haline getirilmiştir. Hücre süspansiyonu 96-kuyulu test mikroplakasının her kuyucuğuna $1 \times 10^{4}$ hücre/kuyu (100 $\mu \mathrm{l})$ olacak şekilde eklenmiştir. Hücreleri içeren plaka $37^{\circ} \mathrm{C}^{\prime}$ de $\% 5 \mathrm{CO}_{2}$ içeren inkübatörde 24 saat bekletildikten sonra kuyulardaki besiyeri uzaklaștırılarak, DMEM-10 içerisinde seyreltilen $\mathrm{BN}$ veya BN-Rd (5-40 $\mu \mathrm{g} / \mathrm{ml}$ ) solüsyonundan $100 \mu \mathrm{l}$ eklenmiştir. Kontrol gurubu hücrelerini içeren kuyulara sadece $100 \mu \mathrm{l}$ DMEM-10 besiyeri eklenmiştir. Tekrar inkübatöre yerleștirilen mikroplakalar 24 ve 48 saat olmak üzere 2 farklı zaman aralığında test edilmek üzere inkübe edilmişlerdir. İnkübasyon zamanı sonunda herbir kuyucuğa $10 \mu \mathrm{l}$ tetrazolyum boyası $(5$ $\mathrm{mg} / \mathrm{ml}$ ) eklenmiş ve mikroplaka 2 saat daha inkübatörde bekletilmiştir. Süre sonunda kuyulardaki besiyeri uzaklaștırılmıș ve oluşan formazan kristalleri $100 \mu \mathrm{l}$ DMSO içerisinde çözünmüştür. Kuyuların absorbansı 570 nm, 690 nm (arka plan) dalga boylarında ölçülmüş ve 570 nm'de ölçülen absorbans değerinden 690 nm'de ölçülen absorbans değeri çıkarılmasıyla elde edilen değerler hücre canlılığı hesaplamalarında kullanılmıştır. Nanoparçacık uygulanan gruplardaki hücre canlılığı, kontrol grubu ile oranlanarak "\%" cinsinden hesaplanmıștır.

\subsection{Hücrelere $B N / B N-R d$ uygulanması ve} 1şı/floresan mikroskobunda görüntüleme

Sitotoksisite sonuçlarına bağlı olarak belirlenen uygun nanoparçacık konsantrasyonları (10 ve $20 \mu \mathrm{g} / \mathrm{ml}$ ), 12-kuyulu plaka içerisinde büyütülen hücrelere uygulanmıştır. Her bir kuyuya $1 \mathrm{ml}$ DMEM-10 besiyeri içerisinde seyreltilen hücreler $\left(1 \times 10^{5}\right.$ hücre $\left./ \mathrm{ml}\right)$ eklenmiş ve plaka bir gece inkübatörde tutulmuştur. Ertesi gün kuyulardaki eski besiyeri DMEM-10 içerisinde seyreltilen BN veya BN-Rd nanoparçacık solüsyonları ile yer değiştirilmiştir. Kontrol kuyularındaki besiyeri $1 \mathrm{ml}$ DMEM-10 ile yer değiştirilmiştir. İnkübatörde 24 saat bekletilen hücreler inkübasyon sonunda iki defa $1 \mathrm{ml}$ steril PBS ile yıkanmış ve hücrelere tutunmayan nanoparçacıkların kuyulardan uzaklaştırılması sağlanmıştır. Taze besiyeri eklenen hücreler floresan mikroskobu (Olympus, IX53) altında incelenmiştir. Ayrıca, nanoparçacık uygulanmış hücreleri morfolojik açıdan incelemek için ışık mikroskobu (Olympus, CKX53) kullanılmıştır.

\section{9. İstatiksel analizler}

Bu çalışmada yer alan tüm deneyler birbirinden bağımsız üç tekrar halinde gerçekleștirilmiş ve çizilen grafiklerde bu deneylerden elde edilen 
verilerin ortalamasi, hesaplanan standart sapmalar ile birlikte gösterilmiștir. MTT canlılık testi sonuçları bir istatistik programı (Minitab 17) kullanılarak analiz edilmiş ve gruplar arasındaki farklar Two-way ANOVA ile test edilmiştir $(\mathrm{p}<0.05)$.

\section{Bulgular}

\subsection{Rodamin 123 bağlı BN nanoparçacıkları}

Reaksiyon sonunda bağlanmayan rodamin 123 boya kalıntıları d-su ile yıkama işlemi sonucu uzaklaştırılmış ve sentezlenen BN-Rd toz halinde oda sıcaklığında saklanmıștır. Toz haldeki BN beyaz renkte gözlenirken, BN-Rd açık pembe renkte gözlenmiştir (Şekil 2). Gerektiğinde toz haldeki nanoparçacıklar d-su ile karıştırılmış $(1 \mathrm{mg} / \mathrm{ml})$ ve sonikatörde $5 \mathrm{dk}$ tutularak süspanse hale getirilmiștir. Süspansiyon içerisindeki nanoparçacıkların lazer ișaretleyicisi ile elde edilen görüntüsü Sekil 2'de gösterilmiştir. Floresan mikroskobu görüntülerine göre kontrol grubunda ışıma gözlenmez iken, BN-Rd nanoparçacık aglomeratlarında kuvvetli ışıma gözlenmiștir (Şekil 2). Yıkama işlemi yapılması ve nanoparçacıkların etrafında çok kuvvetli sinyaller gözlenmesi sebebiyle rodamin 123 boyasının BN'ye bağlandı̆̆ı sonucuna varılmaktadır. Ayrıca d-su içerisinde süspanse edilerek hazırlanan ve oda sıcaklığında 6 aya kadar bekletilen BN-Rd stok solüsyonu aktivitesini korumuş ve sinyal gücünde kayıp gözlenmemiștir. Bekleme süresi sonunda, BN-Rd dibe çöktürüldüğünde, hem BN-Rd'nin renginde hem de süpernatantın renginde değişiklik gözlenmemiștir. Bu durum, Rd ile BN arasında glutaraldehid aracılı kovalent bağ oluşumuna ișaret etmektedir.

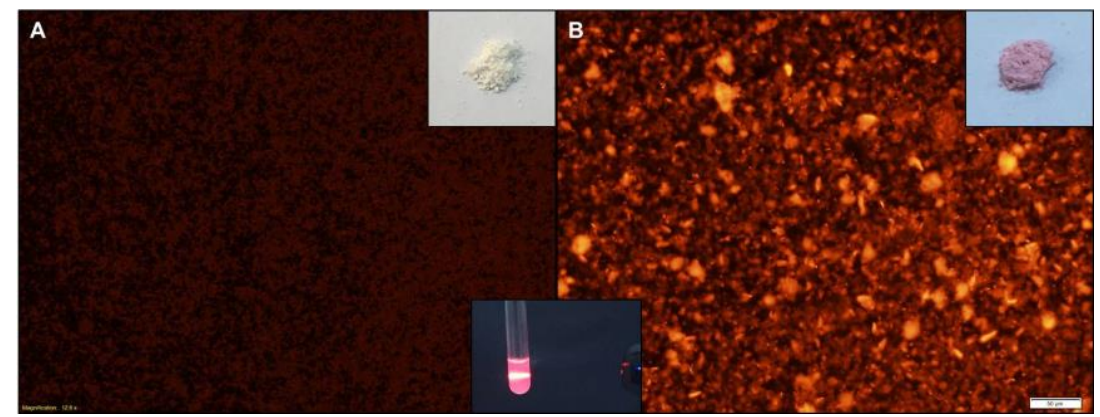

Şekil 2. Floresan mikroskobu görüntüleri; A) BN ve B) BN-Rd. Toz formundaki nanoparçacıklar görüntüler içerisinde sağ üst köșede, süspansiyon içerisinde dağılmıș nanoparçacıkların lazer işaretleyicisi görüntüsü şekil içerisinde altta gösterilmiştir.

\subsection{UV-görünür bölge spektroskopisi}

Rodamin 123 boyasının BN nanoparçacıklarına bağlandığı UV-GB spektroskopisi analizi ile doğrulanmıștır. Rd'nin UV-GB spektroskopisinde $500 \mathrm{~nm}$ dalga boyunda pik verdiği daha önceki çalışmalarda belirtilmiştir [26]. Yaptığımız çalışmada da Rd $500 \mathrm{~nm}$ dalga boyunda net bir pik sergilemiştir. BN'de $500 \mathrm{~nm}$ civarında bir pik görülmez iken BN-Rd'de 450 nm'ye doğru ufak bir kayma ile Rd spesifik piki gözlenmiştir (Şekil 3). BN-Rd'de gözlenen Rd pikinin çok keskin olmamasının sebebi BN'ye bağlanan Rd konsantrasyonun düșük olmasıdır.

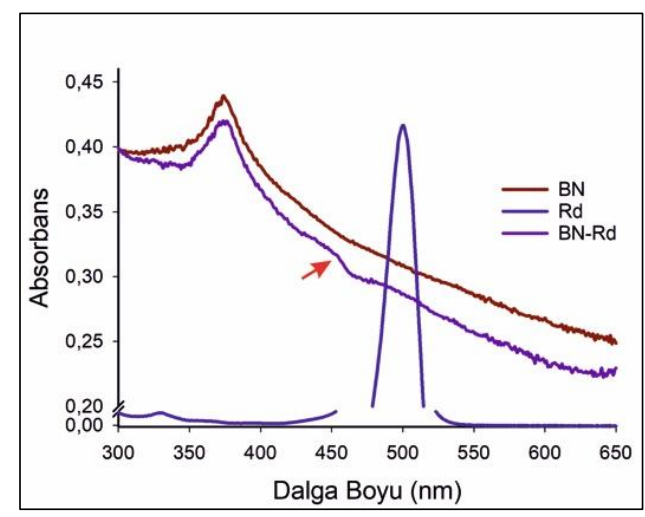

Şekil 3. UV-görünür bölge spektroskopisi 


\subsection{Taramalı elektron mikroskobu ile morfoloji ve boyut analizi}

SEM analizlerinde nanoparçacıkların boyut ve morfojileri incelenmiş ve EDX analizi ile $\mathrm{B}$ ve $\mathrm{N}$ elementlerinin varlığı doğrulanmıştır. Fotoğraflar üzerinde ImageJ programı ile yapılan ölçümlere bağlı olarak BN ve BN-Rd'nin boyutları sirasiyla 40,09 $\pm 5,16 \mathrm{~nm}$ ve $40,01 \pm$ 3,55 nm olarak belirlenmiștir (Șekil 4). Rodamin 123 bağlanmasıyla nanoparçacık boyutunda kayda değer bir değișim gözlenmemiștir. EDX analizinde bor nitrürün yapısında bulunan karakteristik elementler bor ve azotun yanısıra tuz kaynaklı sodyuma ve nanoparçacıkların yayıldığı cam yüzeyden kaynaklı silisyuma rastlanmıștır. SEM analiz sonuçları ticari firmanın belirttiği boyutu teyit eder nitelikte bulunmuştur. Nanoparçacık morfolojisi düzgün olmayan küreciklerin oluşturduğu aglomeratlar olarak gözlenmiştir. Örnek toz halde incelendiği için BN/BN-Rd aglomeratlarının görüldüğü düşünülmekte olup, in vitro çalışmalarda d-su içerisinde süspanse edilen stok solüsyonu sonikasyon ișlemi uygulanarak homojenize edimiştir.
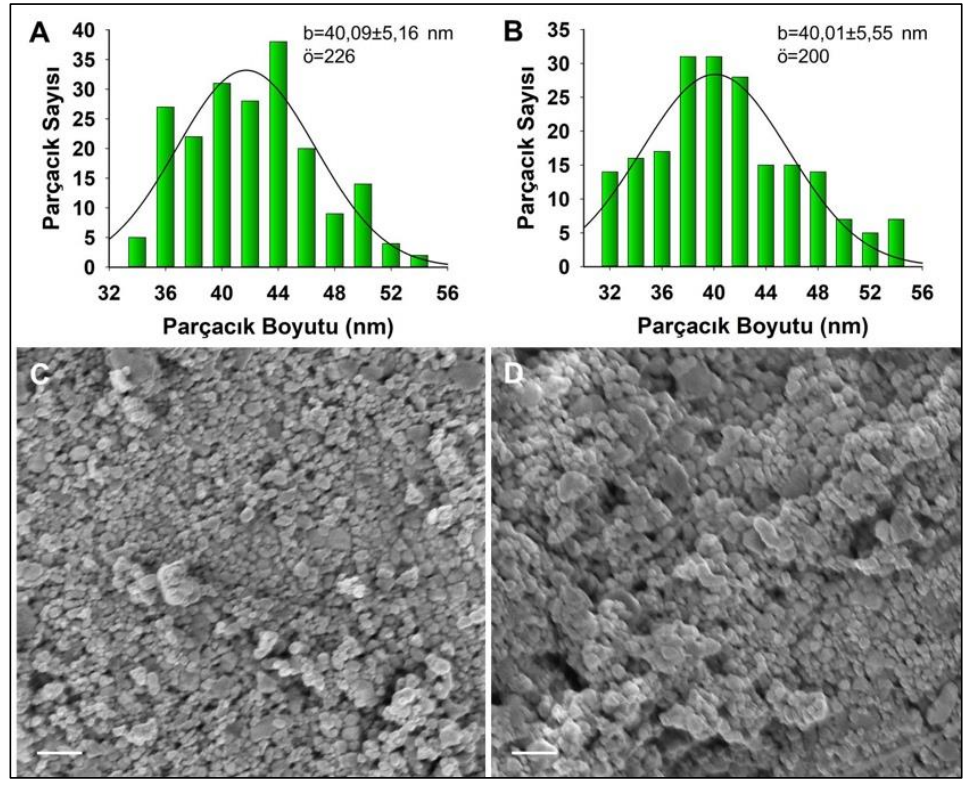

Şekil 4. SEM analizi. ImageJ programında ölçülen nanoparçacıkların boyut dağılımını gösteren histogram grafikleri; A) BN ve B) BN-Rd. SEM görüntüleri; C) BN ve D) BN-Rd nanoparçacıkları. Şekil içerisindeki ölçek barları $200 \mathrm{~nm}$ uzunluğa eş değerdir. (b: boyut; ö=örneklem sayısı)

\subsection{MTT hücre proliferasyon testi}

Farklı konsantrasyonlarda $\quad(5-40 \quad \mu \mathrm{g} / \mathrm{ml})$ hazırlanan BN ve BN-Rd nanoparçacıkları PC-3 ve HEK-293 hücrelerine ayrı ayrı uygulanmıștır. BN ve BN-Rd nanoparçacıkları her iki hücre hattı canlılığı üzerinde de konsantrasyona bağlı bir etki gösterirken, inkübasyon zamanı hücre sitotoksisitesi üzerinde etki göstermemiștir (Şekil 5). Özellikle, 24 saatlik inkübasyon sonunda yüksek konsantrasyonlarda (30 ve 40 $\mu \mathrm{g} / \mathrm{ml}$ ) hücre canlılığı \%50'nin altına düşmüştür. $\mathrm{Bu}$ konsantrasyonlarda, BN BN-Rd'ye oranla daha fazla sitotoksisite sergilemiştir. BN 30 $\mu \mathrm{g} / \mathrm{ml}$ konsantrasyonda PC-3 hücre canlılığını 24 'üncü saat sonunda \%17'ye düşürürken, BN$\mathrm{Rd}$ uygulaması sonunda hücre canlılı̆g $\% 35$ olarak belirlenmiștir. HEK-293 hücreleri üzerinde de benzer șekilde $\mathrm{BN}(30 \mu \mathrm{g} / \mathrm{ml})$ uygulanan grupta hücre canlılı̆g $\% 27$ hesaplanırken, BN-Rd (30 $\mu \mathrm{g} / \mathrm{ml})$ uygulanan grupta hücre canlılığı \%47 olarak belirlenmiştir. Aynı hücrelere $40 \mu \mathrm{g} / \mathrm{ml}$ nanoparçacık uygulandığında 24 saat sonundaki hücre canlılığı BN grubunda \%5 iken BN-Rd grubunda \%35 olarak ölçülmüştür. 
DEÜ FMD 23(68), 595-605, 2021

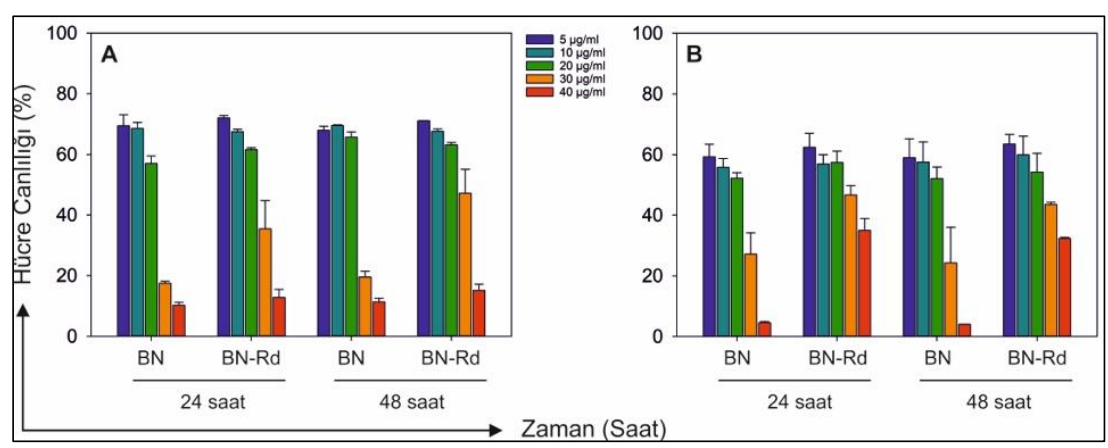

Şekil 5. MTT Hücre canlılık testi. BN ve BN-Rd'nin 5-40 $\mu \mathrm{g} / \mathrm{ml}$ konsantrasyon aralığında; A) PC-3 hücreleri, B) HEK-293 hücreleri üzerindeki etkisi.

3.5. BN/BN-Rd uygulanan hücrelerde sşık mikroskobu ile morfoloji analizi

Sitotoksisite testi uygulanan PC-3 ve HEK-293 hücreleri işık mikroskobu ile görüntülenerek nanoparçacıkların hücre morfolojisi üzerindeki etkileri incelenmiștir (Şekil $6 \mathrm{~A}$ ve B). MTT proliferasyon testini destekler nitelikte bulgular elde edilmiş olup, hiçbir uygulamaya maruz bırakılmamış kontrol grubu hücreleri ile kıyaslandığında 10 ve $20 \mu \mathrm{g} / \mathrm{ml}$ BN ve $B N-R d$ hücre morfolojilerinde kayda değer bir değișime neden olmamıştır. Diğer yandan 30 ve $40 \mu \mathrm{g} / \mathrm{ml}$ nanoparçacık uygulanan gruplarda hücre morfolojileri gözle görülebilir oranda değişime uğramıștır. Özellikle BN $(30 \mu \mathrm{g} / \mathrm{ml})$ uygulanmıș gruplarda hücre morfolojilerindeki değişim daha yoğun gözlenirken, BN-Rd ( $30 \mu \mathrm{g} / \mathrm{ml})$ uygulanan gruplarda hücre bütünlüğünü devam ettiren bazı hücre kümelerinin varlığı dikkat çekmektedir. Sonuç olarak, BN uygulanmış hücrelerde BN-Rd uygulanmış hücrelere oranla daha fazla morfolojik değişim gözlenmiştir.

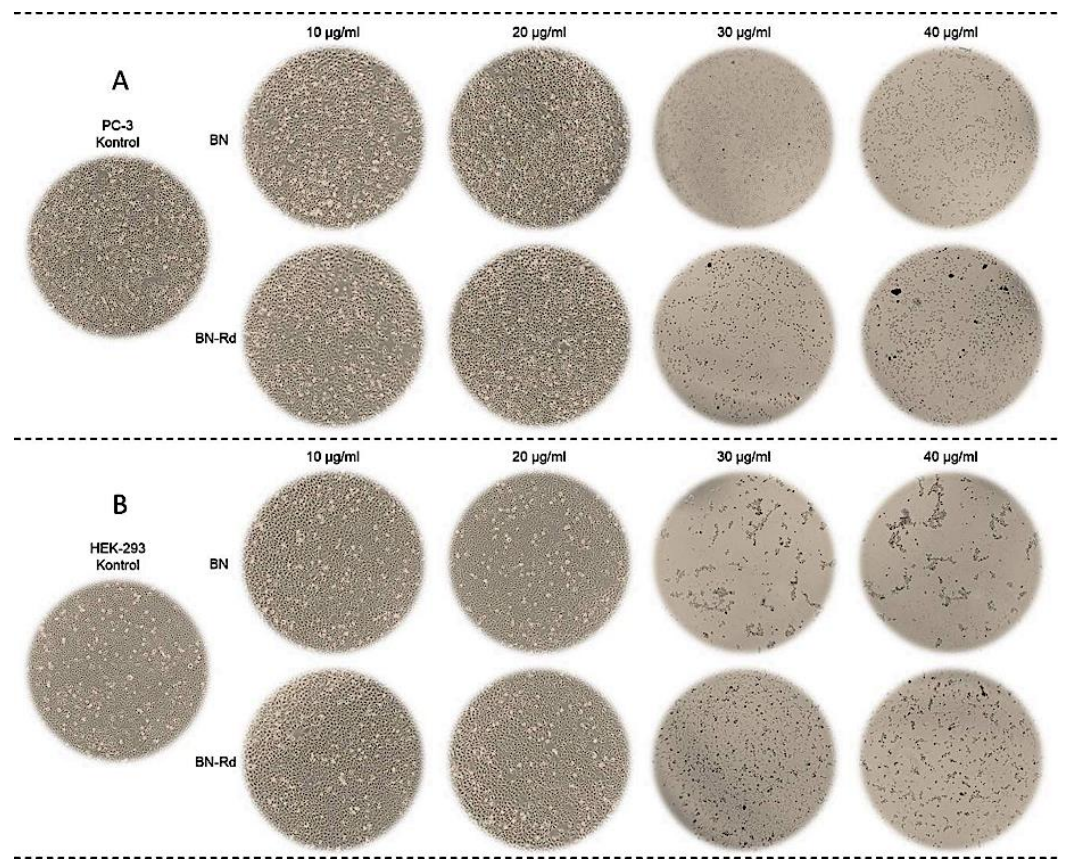

Şekil 6. Işık mikroskobu ile hücre morfolojisi analizi. BN ve BN-Rd'nin 10-40 $\mu \mathrm{g} / \mathrm{ml}$ konsantrasyon aralığında; A) PC-3 hücreleri, B) HEK-293 hücreleri üzerindeki etkisi. 
3.6. BN/BN-Rd uygulanan hücrelerin floresan mikroskobunda görüntülenmesi

MTT hücre proliferasyon testi ve morfoloji analizi bulgularına dayanarak belirlenen konsantrasyonlardaki (10 ve $20 \mu \mathrm{g} / \mathrm{ml}$ ) BN ve BN-Rd nanoparçacıkları PC-3 ve HEK-293 hücrelerine uygulanmış ve bir günlük inkübasyon sonrasında hücre kültürlerinden çekilen floresan mikroskobu görüntüleri Șekil 7'de verilmiştir. Hiçbir uygulamaya maruz bırakılmamış kontrol grubu ve BN uygulanmış gruplarda işıma gözlenmez iken BN-Rd uygulanan gruplarda her iki hücre hattında da ıșıma gözlenmiştir. Yapılan hücre kültürü denemelerinde inkübasyon süresinde dibe çöken ve hücrelere bağlanmayan nanoparçacıkların yanlış pozitif sonuç vermesini önlemek amacıyla floresan mikroskobu analizlerinden önce hücreler iki defa PBS ile yıkanmıș ve son olarak kuyulara taze besiyeri eklenmiştir. Buna göre elde edilen sinyallerin hücre içerisine girmiş veya hücrelere bağlanmış nanoparçacıklardan kaynaklandığı söylenebilmektedir. Floresan mikroskobu görüntülerine göre $10 \mu \mathrm{g} / \mathrm{ml} \quad \mathrm{BN}-\mathrm{Rd}$ konsantrasyonunda daha yoğun ıșıma gözlenmiştir. Bu sonuçlara bağlı olarak ileride yapılması planlanan in vivo denemelerde daha düşük konsantrasyon olan $10 \mu \mathrm{g} / \mathrm{ml}$ BN-Rd tercih edilecektir. Görüntüler incelendiğinde bu konsantrasyonda insan prostat kanseri PC-3 hücrelerinde insan epitel hücresi HEK-293 hücrelerine oranla daha yoğun ışıma gözlenmiștir. Bu farkın sebebinin, kanserli hücre membranının yüksek geçirgenliğinden [27] veya kanserli hücreler arasındaki boșluğun daha geniş olmasından $[9,10]$ kaynaklandığı yorumu yapılabilir.

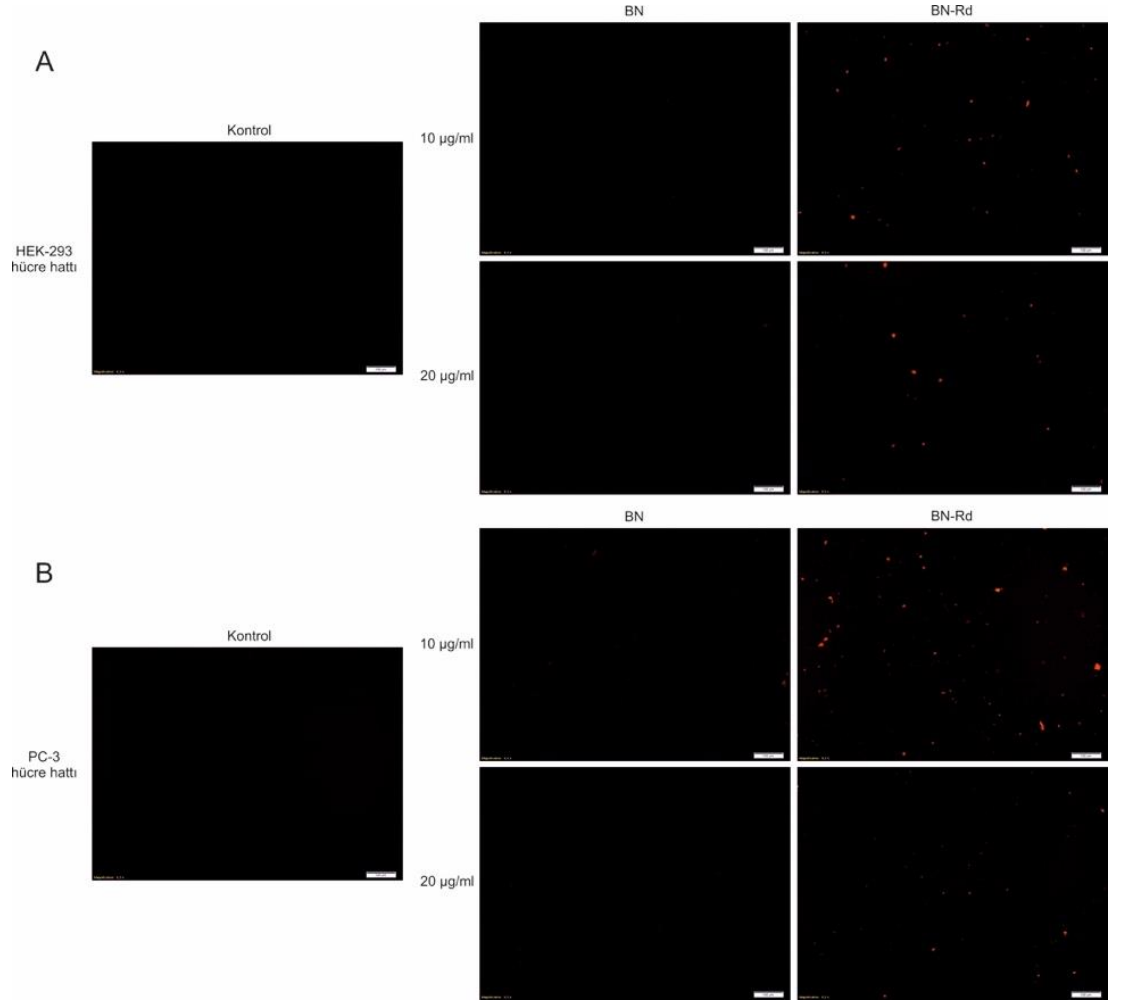

Şekil 7. Floresan mikroskobu analizi. BN ve BN-Rd'nin 10 ve $20 \mu \mathrm{g} / \mathrm{ml}$ konsantrasyon aralığında; A) PC-3 hücreleri, B) HEK-293 hücreleri üzerindeki etkisi. Şekil içerisindeki ölçek barları $100 \mu \mathrm{m}$ uzunluğa eş değerdir.

\section{Tartışma ve Sonuç}

Yapılan çalışmada, biyogörüntüleme amaçlı kulanılmak üzere bor nitrür nanoparçacıkları rodamin 123 floresan boyası ile etiketlenmiș ve üretilen nanoparçacıklar in vitro ortamda enstrümental analizler ve hücre kültürü çalışmaları ile karakterize edilmiştir. Elde edilen 


\section{DEÜ FMD 23(68), 595-605, 2021}

sonuçlar in vivo çalışmalar için ümit vaat edici niteliktedir.

Rodamin 123 floresan boyası glutaraldehit çapraz bağlayıcı ajanı ile başarılı şekilde bor nitrür nanoparçacıklarına kovalent olarak bağlanmıştır. SEM analizlerine göre fotoğraflanan nanoparçacık boyutu ticari firmanın belirttiği şekilde yaklaşık $40 \mathrm{~nm}$ olarak belirlenmiștir. Rodamin 123 bağlanmasıyla nanoparçacık boyutunda bir değişiklik gözlenmemiştir. Literatürde, nanoparçacık büyüklüğünün ve șeklinin hücre içerisine giriște ve hücreden uzaklaștırılmasında önemli rol oynadığı belirtilmektedir [28]. Buna göre, küçük $\left(\begin{array}{ll}\sim 0 \mathrm{~nm}\end{array}\right)$ boyutlu ve küresel şekilli nanoparçacıkların (çubuksu şekilli nanoparçacıklara göre) hücre içerisine daha hızlı ve yüksek konsantrasyonda alındığı bildirilmektedir [28,29]. Bu sonuçlara göre çalışmamızda kullandığımız yaklaşık $40 \mathrm{~nm}$ boyuta sahip ve küresel şekilli BN nanoparçacıklarının biyogörüntüleme için ideal boyuta ve șekle sahip olduğu sonucuna varılabilir.

Hücre canlılığı testlerine göre $20 \mu \mathrm{g} / \mathrm{ml}$ eșik değeri olarak bulunmuş olup bu konsantrasyonun üzerinde hücre canlıllğ̆ \%50'nin altına düșerken bu konsantrasyon ve altında hücre canlılığı \%60-70 civarında tespit edilmiștir. Literatürde $10 \mu \mathrm{g} / \mathrm{ml}$ üzerindeki bor nitrür nanotüplerinin tetrazolyum tuzları ile etkileşerek MTT test sonuçlarını etkileyebileceğini ve hatalı sonuç vereceği tartışılmaktadır [30]. Bu durum, hücrelerin ışık mikroskobunda oldukça sağlıklı gözlendiği konsantrasyonlarda $(5-20 \mu \mathrm{g} / \mathrm{ml})$, MTT testinde hücre canlılığının \%60-\%70 gibi düşük sayılabilecek bir değerde ölçülmesinin sebebini açıklamaktadır. Işık mikroskobu altında yapılan morfoloji analizi de MTT hücre canlılığı testini destekler nitelikte olup, $20 \mu \mathrm{g} / \mathrm{ml}$ üzerindeki konsantrasyonlarda hücre morfolojisinde gözle görülebilir değișimler gözlenmiştir. Benzer şekilde, başka bir çalışmada da MTT testi sonuçlarına göre bor nitrür nanotüplerinin HEK293 hücreleri üzerinde $20 \mu \mathrm{g} / \mathrm{ml}$ üzerindeki konsantrasyonlarda sitotoksik olduğu ve hücre morfolojisinde değişimlere yol açtığı rapor edilmiștir [31]. Yaptığımız MTT hücre canlılığı analizlerine göre $30 \mu \mathrm{g} / \mathrm{ml}$ ve $40 \mu \mathrm{g} / \mathrm{ml} \mathrm{BN}$ konsantrasyonlarının sitotoksik etki gösterdiği ışık mikroskobu görüntüleri ile de doğrulanmıştır. Bu çalışmada, elde ettiğimiz bulgular doğrultusunda $10 \mu \mathrm{g} / \mathrm{ml}$ ve $20 \mu \mathrm{g} / \mathrm{ml}$ konsantrasyonlar hücrelere uygulanarak $\mathrm{BN}$ Rd'nin biyogörüntüleme uygulamalarında kullanım potansiyeli araştırılmıștır.

BN-Rd uygulanan PC-3 ve HEK-293 hücrelerinde floresan mikroskobu altında ışıma görülmüştür. BN-Rd $(10 \mu \mathrm{g} / \mathrm{ml})$ uygulanan prostat kanseri hücre tipi olan PC-3 hücrelerinin sağlıklı epitel hücre tipi olan HEK-293 hücrelerine oranla daha yoğun ışıma yaptığı gösterilmiştir. Bu bulgular kanserli hücre zarının daha geçirgen olması veya tümör dokusunun normal dokuya göre daha fazla geçirgen olması durumu ile açılklanabilir. Yapılan çalışmalarda BN nanoparçacıklarının hücre içerisine endositoz yoluyla girebildiği bilinmektedir $[18,32]$. Tümör dokusunun yüksek geçirgenliğine dayanan pasif hedefleme yönteminde 40-200 nm aralığındaki nanoparçacıklar tercih edilmektedir $[9,10]$. Çalışmamızda kullanılan nanoparçacık boyutunun $(40 \mathrm{~nm})$ pasif hedefleme (dolayısıyla biyogörüntülme) için uygun olduğu görülmektedir.

Sonuç olarak in vitro ortamda en uygun konsantrasyon olarak belirlenen $10 \mu \mathrm{g} / \mathrm{ml} \mathrm{BN-}$ $\mathrm{Rd}$ konsantrasyonunun in vivo testler ve klinik çalışmalarla desteklenmesi ve bor nitrür nanoparçacıklarının biyogörüntüleme amaçlı kullanım potansiyelinin daha ayrıntılı olarak araștırılması gerekmektedir. Katma değeri yüksek bor ürünlerinin sağlı alanında kullanımı, zengin bor yataklarına sahip ülkemizin ekonomisine katkı sağlayacaktır.

\section{Teșekkür}

Bu çalıșmanın ön deneme sürecine katkı sağlayan İzmir Özel Yeşeren Fen Lisesi öğretmenlerinden Adil CAN'a ve öğrencisi İdil Bilge TUNÇ’a teșekkür ederim.

\section{Kaynakça}

[1] Apostolova, N., Rovira-Llopis, S., Baldoví, H.G., Navalon, S., Asiri, A.M., Victor, V.M., Garcia, H., Herance, J.R. 2015. Ceria nanoparticles with rhodamine $\mathrm{B}$ as a powerful theranostic agent against intracellular oxidative stress, RSC Advances, Cilt. 5(97), s. 79423-79432. DOI: https://doi.org/10.1039/c5ra12794g

[2] Aydin, H. 2018. Nanoyapılı Hegzagonal Bor Nitrür Üretimi ve Karakterizasyonu, Firat Üniversitesi Mühendislik Bilimleri Dergisi, Cilt. 30(2), s. 269-275. DOI:

https://dergipark.org.tr/en/pub/fumbd/issue/391 97/461582

[3] Chessel, A. 2017. An Overview of data science uses in bioimage informatics, Methods, Cilt. 115, s. 110-118. DOI: https://doi.org/10.1016/j.ymeth.2016.12.014 


\section{DEÜ FMD 23(68), 595-605, 2021}

[4] Etimaden - TÜRKIYE'DE BOR. http://www.etimaden.gov.tr/turkiyede-bor (Erişim Tarihi 29.07.2020)

[5] Forster, S., Thumser, A.E., Hood, S.R., Plant, N. 2012 Characterization of rhodamine-123 as a tracer dye for use in in vitro drug transport assays, PLoS ONE Cilt. 7(3), e33253. DOI: https://doi.org/10.1371/journal.pone.0033253

[6] Kainthola, A., Bijalwan, K., Negi, S., Sharma, H. Dwivedi, C. 2020. Hydrothermal synthesis of highly stable boron nitride nanoparticles, Materials Today: Proceedings, Cilt. 28, s. 138-140. DOI https://doi.org/10.1016/j.matpr.2020.01.452

[7] Kumar, V., Lahiri, D., Lahiri, I. 2018. Synthesis of Boron Nitride Nanotubes and Boron Nitride Nanoflakes with Potential Application in Bioimaging, Materials Today: Proceedings, Cilt. 5(8), s. 1675616762.

https://doi.org/10.1016/j.matpr.2018.06.037

[8] Pamukcu, A., Portakal, H.S., Eroglu, E. 2018. Terapötik Moleküllerin Aktariminda Kullanilan Yeni Nesil Biyomalzemeler, Erzincan Üniversitesi Fen Bilimleri Enstitüsü Dergisi, Cilt. 11(3), s. 524-542. DOI: $10.18185 /$ erzifbed.339405.

[9] Kutova, O.M., Guryev, E.L., Sokolova, E.A., Alzeibak, R., Balalaeva, I.V. 2019. Targeted Delivery to Tumors: Multidirectional Strategies to Improve Treatment Efficiency, Cancers, Cilt. 11(1), s. 68. DOI: https://doi.org/10.3390/cancers11010068

[10] Raj, S., Khurana, S., Choudhari, R., Kesari, K.K., Kamal, M.A., Garg, N., Ruokolainen, J., Das, B.C., Kumar, D 2019. Specific targeting cancer cells with nanoparticles and drug delivery in cancer therapy, Seminars in Cancer Biology, DOI: https://doi.org/https://doi.org/10.1016/j.semcanc er.2019.11.002

[11] Eroglu, E., Portakal, H.S., Pamukcu, A. 2020. A New Generation Nanotherapeutic: pHEMA-Chitosan Nanocomposites in siRNA Delivery, Current Nanoscience, 16.

DOI $10.2174 / 1573413716666200110093715$

[12] Eroglu, E., Tiwari, P.M., Waffo, A.B., Miller, M.E., Vig, K., Dennis, V.A., Singh, S.R. 2013. A nonviral pHEMA+chitosan nanosphere-mediated highefficiency gene delivery system, International journal of nanomedicine, Cilt. 8, s. 1403-1415. DOI: https://doi.org/10.2147/IJN.S43168

[13] Malik, N., Arfin, T., Khan, A.U. 2019. Chapter 13 Graphene nanomaterials: chemistry and pharmaceutical perspectives. ss. 373-402. Malik, N., Arfin, T., Khan, A.U. ed. 2019. Nanomaterials for Drug Delivery and Therapy, Elsevier, 551s. DOI: https://doi.org/https://doi.org/10.1016/B978-012-816505-8.00002-3

[14] Han, W., Ma, Z., Liu, S., Ge, C., Wang, L., Zhang, X. 2017. Highly-dispersible boron nitride nanoparticles by spray drying and pyrolysis, Ceramics International, Cilt. 43(13), s. 10192-10200. DOI https://doi.org/10.1016/j.ceramint.2017.05.045

[15] Pandey, S., Bodas, D. 2020. High-quality quantum dots for multiplexed bioimaging: A critical review, Advances in Colloid and Interface Science, Cilt. 278, $\mathrm{s}$ 102137. https://doi.org/10.1016/j.cis.2020.102137
[16] Qi, J., Hu, X., Dong, X., Lu, Y., Lu, H., Zhao, W., Wu, W. 2019. Towards more accurate bioimaging of drug nanocarriers: turning aggregation-caused quenching into a useful tool, Advanced Drug Delivery Reviews, Cilt. 143, s. 206-225. DOI: https://doi.org/10.1016/j.addr.2019.05.009

[17] Shen, Q., Wang, S., Yang, N. Di, Zhang, C., Wu, Q., Yu, C. 2020. Recent development of small-molecule organic fluorophores for multifunctional bioimaging in the second near-infrared window, Journal of Luminescence, Cilt. 225, s. 117338. DOI: https://doi.org/10.1016/j.jlumin.2020.117338

[18] Sukhorukova, I.V, Zhitnyak, I.Y., Kovalskii, A.M., Matveev, A.T., Lebedev, O.I., Li, X., Gloushankova, N.A., Golberg, D., Shtansky, D.V. 2015. Boron Nitride Nanoparticles with a Petal-Like Surface as Anticancer Drug-Delivery Systems, ACS Applied Materials \& Interfaces, Cilt. 7(31), s. 17217-17225. DOI: https://doi.org/10.1021/acsami.5b04101

[19] Tabaković, A., Kester, M., Adair, J.H. 2012. Calcium phosphate-based composite nanoparticles in bioimaging and therapeutic delivery applications, Wiley Interdisciplinary Reviews: Nanomedicine and Nanobiotechnology, Cilt. 4(1), s. 96-112. DOI: 10.1002/wnan.163

[20] Zhang, W.H., Hu, X.X., Zhang, X.B. 2016. Dye-doped fluorescent silica nanoparticles for live cell and in vivo bioimaging, Nanomaterials, Cilt. 6(5), s. 81. DOI: $10.3390 /$ nano6050081

[21] Chandra, S., Das, P., Bag, S., Laha, D., Pramanik, P. 2011. Synthesis, functionalization and bioimaging applications of highly fluorescent carbon nanoparticles, Nanoscale, Cilt. 3(4), s. 1533-1540. DOI: $10.1039 / \mathrm{CONR} 00735 \mathrm{H}$

[22] Singh, A., Jha, S., Srivastava, G., Sarkar, P., Gogoi, P. 2013. Silver Nanoparticles As Fluorescent Probes: New Approach For Bioimaging, International Journal of Scientific \& Technology Research, Cilt. 2(11), s. 153-157.

[23] Xue, Y., Lee, J., Kim, H.-J., Cho, H.-J., Zhou, X., Liu, Y., ... Khademhosseini, A. 2020. Rhodamine Conjugated Gelatin Methacryloyl Nanoparticles for Stable Cell Imaging, ACS Applied Bio Materials, Cilt: 3(10), s. 6908-6918.

https://dx.doi.org/10.1021/acsabm.0c00802

[24] Kumar, V., Nikhil, K., Roy, P., Lahiri, D., Lahiri, I. 2016. Emergence of fluorescence in boron nitride nanoflakes and its application in bioimaging, RSC Advances, Cilt: 6(53), s. 48025-48032. DOI: 10.1039/c6ra05288f

[25] He, Z., Zhao, J., Li, F., Zhang, D., Guo, F., Guo, H., Wang, X., Hu, H. 2021. In situ synthesis of polymer-modified boron nitride nanosheets via anionic polymerization, Applied Surface Science, Cilt: 537(53), s. 147966. DOI: https://doi.org/10.1016/j.apsusc.2020.147966

[26] Kumari, R., Singh, S., Monisha, M., Bhowmick, S., Roy, A., Das, N., Das, P. 2016. Hierarchical coassembly of DNA-triptycene hybrid molecular building blocks and zinc protoporphyrin IX, Beilstein Journal of Nanotechnology, Cilt: 7(1), s. 697-707. DOI: https://doi.org/10.3762/bjnano.7.62

[27] Zalba, S., Ten Hagen, T.L. 2017. Cell membrane modulation as adjuvant in cancer therapy, Cancer 
treatment reviews, Cilt. 52, s. 48-57. DOI: https://doi.org/10.1016/j.ctrv.2016.10.008

[28] Chithrani, B.D.; Chan, W.C.W. 2007. Elucidating the Mechanism of Cellular Uptake and Removal of Protein-coated Gold Nanoparticles of Different Sizes and Shapes, Nano Letters, Cilt. 7, s. 1542-1550. DOI: $10.1021 / \mathrm{nl070363y}$.

[29] Chithrani, B.D.; Ghazani, A.A.; Chan, W.C.W. 2006 Determining the Size and Shape Dependence of Gold Nanoparticle Uptake into Mammalian Cells, Nano Letters, Cilt. 6, s. 662-668. DOI: 10.1021/nl052396o.

[30] Ciofani, G., Danti, S., Genchi, G.G., Mazzolai, B. Mattoli, V. 2013. Boron Nitride Nanotubes: Biocompatibility and Potential Spill-Over in Nanomedicine, Small, Cilt. 9, s. 1672-1685. DOI: 10.1002/smll.201201315

[31] Horváth, L., Magrez, A., Golberg, D., Zhi, C., Bando, Y., Smajda, R., Horvath, E., Forró, L., Schwaller, B. 2011. In Vitro Investigation of the Cellular Toxicity of Boron Nitride Nanotubes, ACS NANO, Cilt. 5, s. 38003810. DOI: $10.1021 / \mathrm{nn} 200139 \mathrm{~h}$.

[32] Rasel, A., Li, T., Nguyen, D., Singh, S., Zhou, Y., Xiao, Y., Gu, Y.T. 2015. Biophysical response of living cells to boron nitride nanoparticles: uptake mechanism and bio-mechanical characterization. Journal of Nanoparticle Research, Cilt. 17(11), s. 441. DOI: 10.1007/s11051-015-3248-2. 